\title{
NORBERT ELIAS: \\ o esboço de uma sociologia das emoções
}

\author{
por Elder Patrick Maia Alves*
}

ELIAS, Norbert. A peregrinação de Watteau à ilha do amor. Rio de Janeiro: Jorge Zahar, 2005. 76 p.

O ensaio, transformado em livro e recentemente publicado, $A$ peregrinação de Watteau à ilha do amor, do sociólogo Norbert Elias, retém como núcleo de problematização a experiência estética moderna, nos termos de uma redefinição e modulação de uma certa configuração de sensibilidade, que, em um primeiro momento, brota no círculo artístico da rue du Doyenne, na Paris da primeira metade do século XIX, mas que logo se irradia por outros segmentos sociais, penetrando e constituindo as emoções de muitas gerações de artistas, como a do escritor e poeta Boudelaire. O texto permite antever a contundência metodológica e, sobretudo, a sagacidade e tenacidade de um senhor já aquela altura (o ensaio é escrito em 1983) octogenário. Assim como em outros trabalhos, Norbert Elias mobiliza muitas cadeias de interdependência e, em poucas páginas, faz da tela de Antoine Watteau o dado empírico que lhe permite acessar o campo de produção/consumo simbólico em que a tela se situa, munindo-o de um exemplo pictórico que o faz percorrer três séculos. Como corolário, é possível afirmar que Elias não tem como desiderato nesse ensaio incursionar pela Sociologia da Arte, nem tampouco fazer da tela objeto sociológico, mas antes verificar como o quadro recuperado e ressignificado nos círculos franceses cem anos após sua pintura - desencadeou nas produções culturais (como poemas e

Doutorando em Sociologia na Universidade de Brasília (UnB). 
livros) novos dispositivos de sensibilidades envolvendo os períodos pré e pós Revolução Francesa. Por isso, o quadro de Watteau é apenas o ponto de partida, ou melhor, um elo na costura da trama simbólica da transição do século XVIII para o século XIX.

O autor inicia o texto fornecendo toda a sorte de informações acerca da tela de Watteau, o que o obriga a consumir boa parte do ensaio. O quadro, cujo nome é modificado ao longo da transição do século XVIII para o XIX, é a cristalização pictórica de um mito grego, deslocado durante a renascença européia: a imagem da ilha de Citera, pequena ilha localizada no vasto arquipélago grego, aparece como símbolo de um fictício santuário de amor, destino de muitos casais de jovens amantes e objeto de sonhos e desejos, uma espécie de utopia secular. Na gênese social do mito, a ilha de Citera aparece como local perigoso, habitado pela ardilosa e atraente deusa do amor. $\mathrm{O}$ quadro de Watteau é assim resultado da inspiração artística eivada de narrativas mitológicas que foram se modificando ao longo do tempo. Durante o período em que o quadro foi confeccionado, nos primeiros anos do século XVIII, a imagem da ilha de Citera assumiu uma representação de sublimação e fruição do amor. A partir dessa digressão, o autor passa a examinar os minuciosos aspectos pictóricos da obra de Watteau, isto é, a disposição dos casais, as tintas, as gradações das cores, o cenário em si, os rostos das personagens, os pequenos cupidos, a embarcação utilizada para o embarque à ilha, etc.

Em seguida, a partir do segundo fragmento do ensaio, Elias se põe a analisar a trajetória do pintor Antonie Watteau, seu ingresso na Academia Real (1712) e sua posição no interior da sociedade cortesã francesa. A partir daí, o autor começa a compor seu argumento. Verificando as sucessivas mudanças do nome da tela, quando da apresentação da mesma para o ingresso na Academia Real de Artes, quando passa a se chamar Uma festa elegante, Elias apresenta o que chama de mudança na balança de poder, envolvendo produtores e consumidores simbólicos durante dois períodos distintos: o que vai do século XVI até a Revolução Francesa, e o que marca a ascensão dos grupos profissionais burgueses do século XIX. 
Segundo o autor, durante os anos que antecederam a morte de Luís XIV até a Revolução, um estilo artístico se consolidou, marcando uma sutil, mas importante transição: do grave e austero barroco para o "galante" e "elegante" rococó. O antigo regime, com seu centro irradiador e aglutinador de poder, não criava maiores canais de acesso político e alteração nos dispositivos de poder. Com o desmantelamento da ordem estamental empreendido pelos grupos revolucionários durante e após a Revolução, alterou-se o quadro de formação das opiniões e das atividades discursivas. Aqui o autor inicia uma formulação presente em outros trabalhos ${ }^{1}$ e, apesar de algumas distinções, também presente em escritos de Bourdieu e Habermas. A partir da ascensão dos grupos comercias, artesãos, empresariais e profissionais a alguns postos de mando e, sobretudo, com a dissolução dos muitos privilégios econômicos existentes em face do domínio das aristocracias nobiliárquicas, as atividades de fruição artística responsável pela produção do "bom" gosto - fora inteiramente deslocada. Na trama simbólica das sociabilidades cortesãs, o artistaprodutor gozava de pouca autonomia estilística e formal, importando muito pouco suas avaliações e critérios: o que contava mesmo eram os desígnios dos setores aristocráticos, que consumiam e fruíam as obras culturais. No interior dessa figuração, o artista cortesão cumpria apenas o papel de fornecedor, um capataz, quando muito um funcionário do entretenimento cortesão.

Após a revolução e, sobretudo, com a consolidação de uma ética do trabalho, de onde os grupos profissionais retiram suas legitimidades e produzem seus valores e estimas, o monopólio do gosto foi deslocado, passando a ser exercido pelos círculos artísticos urbanos - clubes e associações de artistas, poetas e pintores reunidos em torno da produção de artigos e bens culturais. Segundo Elias, durante o Antigo Regime, havia um cânone estético do bom gosto definido, onde o espaço para grandes polêmicas e disputas simbólicas estava restritos. O monopólio do gosto era sustentado por uma sociedade do ócio, bem integrada e politicamente coesa, infensa a grandes transformações nos códigos de apreciação e na linguagem estética. Os círculos de artistas, muitos dos quais pertencentes a nobrezas decadentes, passaram a se dedicar à critica sistemática, no 
desenvolvimento de uma especialização, no cultivo de uma personalidade única - de criação e avaliação -, de uma sensibilidade irredutível à simples compra e venda, habilitada e forjada para apreender o belo, o bom e o verdadeiro. Só então, segundo o autor, surge uma figuração particular, característica da relação envolvendo artista e público, consumidor e produtor, isto é, toda uma atividade de especialização e autonomização e, por conseguinte, monopolização do "bom" gosto por parte dos círculos especializados no trabalho com as cores, com os gêneros, os estilos, as combinações, as escolas, etc.

Foi precisamente no interior de um desses círculos que a tela de Watteau foi descoberta, e é aqui que o autor faz ver a seletividade pela qual passa a obra do pintor francês. Nos primeiros anos após a Revolução, todo e qualquer estilo artístico que lembrasse a economia gestual e os traços das sociabilidades aristocráticas (como é o caso da tela de Watteau) eram detratados - o estilo rococó, do qual a tela de Watteu é um dos grandes expoentes, recebe esta denominação no período pós-revolucionário. O termo rococó denota um certo desdém, uma espécie de pecha inferiorizante cunhada em meio aos arroubos revolucionários. Não obstante, no final dos anos 30 do século XIX, o mesmo Watteau passa a ser objeto de culto. Após a progressiva (mesmo com a restauração monárquica) consolidação de uma economia monetária e mediante a ascensão dos muitos grupos comercias ao poder, além das mais diversas batalhas campais envolvendo os muitos grupos sociopolíticos, o século XVIII passa a comparecer como um ideal de beleza e harmonia na experiência estética dos círculos artísticos de então.

Essa inversão de avaliação da tela de Watteau, segundo Elias, dá-se mediante muitos feixes de relações. Importa aqui aprender a condensação de uma narrativa e a potencialização de um ideal estéticoromântico no decurso do século XIX. O período pré-revolucionário passou a apresentar, segundo a percepção estética dos círculos artísticos, um primado de elegância, de bom tom, de celebração, de festas, enfim, de encantamento. Esse ideal passou a mover a percepção criadora de muitos poetas, pintores e escritores. Entre 
eles, o poeta e escritor Gerard de Nerval, que publicou uma série de poemas acerca do quadro de Watteau e da ilha de Citera, entre eles o ensaio Voya à Cythere. A partir de Nerval todo um ideal de busca de um paraíso idílico, representado pela tela de Watteau, é levado a cabo pelos jovens artistas do circulo rue du Doyenne. Eram festas, bailes, comemorações em grandes salões, adoção das roupas do período pré-revolucionário, entre outros. O estilo rococó perde, assim, todo o espinho estigmatizante. Como corolário, Gerard de Nerval resolve viajar à então desejada ilha de Citera - então, nos anos 40 do século XIX, sob domínio britânico. O que se viu, segundo Elias, fora a antípoda acabada dos ideais de amor e beleza inscritos na tela de Watteau e corroborados pelos círculos artísticos do período. Nerval encontrou uma ilha árida, feita de dor e angústia - tratava-se tãosomente de um centro de punição da coroa britânica.

Segundo Elias, esta experiência de Nerval é emblemática e pode ser aduzida como um paradigma para se entender as estruturas de poder das sociedades urbano-industriais-profissionais dos séculos XIX e XX, nos termos de formação de uma nova estrutura social de sentimentos. A experiência aterradora de Nerval, isto é, o conflito irreconciliável entre ideal e real, ganha novos e potentes contornos na produção poética de Boudelaire, que, por seu turno, escreve Voyage à l'isle de Cythere. Por outro lado, Vítor Hugo também aborda o tema, publicando vários temas acerca de Citera, atestando o quanto o tema da ilha do amor assaltara a atenção de poetas e escritores. Em um de seus poemas (As flores do mal), Boudelaire retoma o tema dos aspectos sombrios da realidade da ilha de Citera experimentados por Nerval em sua viagem. No entanto, segundo Elias, Boudelaire não poupa os leitores: explora, na linguagem poética de seus textos, toda sorte de dores e sofrimentos; de corpos sendo dilacerados por abutres e forcas repletas de corpos mutilados.

Após mobilizar Boudelaire em sua análise, Elias encaminha seu argumento para o final, no qual fica claro seu problema analítico e a importância da sociogênese. Segundo Elias as utopias coletivas que precederam a Revolução Francesa encerravam maiores chances de serem realizadas. As transformações engendradas na passagem 
do século XVIII para o XIX fizeram emergir esquemas utópicos (ideais de felicidade) em franca concorrência com a realidade. Essa cesura se expressa de maneira irrevogável nos artistas mobilizados ao longo do ensaio. Para Elias, as sociedades urbano-industriaisprofissionais do século XIX e, sobretudo, do século XX passaram a compor uma figuração tensa e recalcitrante envolvendo desejo e medo, ou para ser mais fiel ao pensamento do autor, uma figuração desejo/ medo. O hiato entre real e ideal trouxe toda sorte de angústias e frustrações, tema que marcou mais de perto a sensibilidade de poetas e artistas. No entanto, o amálgama tenso entre real e ideal não significa, para o autor, nenhum estado de anomia, mas tão-somente que essas duas dimensões compõem uma figuração social e definem a produção sociológica da realidade, uma realidade ideacional e ao mesmo tempo concreta. Não obstante, este é apenas um flanco da conclusão. A pergunta de Elias é mais sutil: interessa-lhe indagar sobre as própria condições de emergência do ideal utópico moderno. Assim, sua pergunta é: em que momento o julgado mau, feio e falso torna-se um tema artístico - em contraposição ao bom, belo e verdadeiro -, legitimando e consagrando certos bens culturais, passando a ser tema da boa literatura?

Para Elias são exatamente as contingências da passagem do século XVIII para o século XIX que realizam essa transformação. Essa alquimia simbólica, diria Bourdieu, foi operada no interior dos círculos (autonomizados em função dos desdobramentos da Revolução), que se consolidaram a partir da expansão dos mercados simbólicos no século XX. Ante isso, fica claro o desenho metodológico de Norbert Elias: o quadro de Wateau é o registro empírico para se acessar o campo de produção/consumo de bens simbólicos talhado no período pré e pós-revolucionário, no qual se situam nomes como Gerard de Nerval, Boudelaire e Vitor Hugo. Mediante a autonomização dos círculos artísticos, o ideal romântico se robustece e então se confronta com o impávido real. Este traz consigo toda sorte de angústias, dissabores, resignações e privações, passando a ser, então, tema da "boa" arte , um tema recorrente e legítimo. Assim, a cesura entre real e ideal, cada vez mais abismal e irreconciliável, compõe uma figuração social dilacerante, feita de desejo e medo. 
Aqui dormita o fundamento metodológico para a escolha de um tema artístico para o tratamento empírico-sociológico: o campo de produção simbólica, e mais precisamente seus artífices (escritores, poetas, pintores e também filósofos e intelectuais em geral), constitui uma usina de produção de sentido e potencializador de narrativas e cosmologias de vida. Assim, o que em meados do século XIX estava restrito a alguns círculos de artistas invadiu também a percepção filosófica e científica. Mediante a longa e maciça produção e consumo cultural das sociedades urbano-industriais-profissionais do século XX, o conflito ideal versus real, e sua figuração correspondente (desejo/ medo), tornou-se parte da estrutura social de personalidade de muitos grupos humanos contemporâneos. ${ }^{2}$

\section{Notas}

1 Ver Mozart: sociologia de um gênio, de Norbert Elias.

2 Ver o conceito de habitus em Norbert Elias e Pierre Bourdieu. 